\title{
Acquired immunity: immunosenescence and physical activity
}

\author{
Lucia Malaguarnera $\cdot$ Erika Cristaldi $\cdot$ Helga Lipari • \\ Mariano Malaguarnera
}

Received: 13 December 2007 / Accepted: 7 August 2008 / Published online: 28 August 2008

(C) EGREPA 2008

\begin{abstract}
Several lines of evidence indicate that infectious diseases, cancer, and autoimmune disorders occur more frequently in elderly people, thus suggesting that altered function of immune organs and cells, such as thymus and $\mathrm{T}$ and B lymphocytes are of primary importance in the pathogenesis of these diseases. Furthermore, old subjects are less responsive to vaccine than younger because of immune changes. The most common changes accompanying the adaptive immune system include decrement of $\mathrm{T}$ and $\mathrm{B}$ cells proliferation, repertoire degeneracy, increase of the memory cell type, decreased numbers of naive cells, and shift from T helper 1 (Th1) to T helper 2 (Th2) response. Regular exercise in the elderly may improve the alterations in acquired immunity which follow the physiological process of aging, allowing a major resistance against external pathogens and a better quality of life.
\end{abstract}

Keywords Acquired immunity · Immunosenescence .

Regular exercise $\cdot$ Naïve T cells

\section{Introduction}

Aging represents an important challenge to public health. It is associated with weakening of the organism and a decreased performance of the physiological system, including the

E. Cristaldi $\cdot$ H. Lipari $\cdot$ M. Malaguarnera $(\bowtie)$

Department of Senescence, Urological and Neurological Sciences,

Azienda Ospedaliera Cannizzaro, via Messina 829, Cannizzaro,

95124 Catania, Italy

e-mail: malaguar@unict.it

L. Malaguarnera

Department of Biomedical Sciences, University of Catania,

Catania, Italy immune system. Thus, the term immunosenescence designates a sort of remodeling of the immune response [45]. Whether the alterations in immune responses contribute to morbidity and mortality in elderly still remain a tangled question.

Elderly subjects display decline of absolute lymphocyte counts [5]. They have various suppressed immune parameters [15], such as decreased proliferative lymphocyte responses or anergic lymphocytes [55]. The alterations of the immune system in the elderly are linked principally to replicative senescence, which may limit $\mathrm{T}$ cell clonal expansion and alterations associated with the thymus involution. In addition, following stimulus with antigens, mitogens, or anti-CD3 antibody, irregularities of apoptosis, changes in the peripheral lymphocyte pool, in the cytokine production profile, in the signaling function, and in the replicative ability have been described (Table 1 ).

The most common changes accompanying the adaptive immune system include decrement of $\mathrm{T}$ - and B-cell proliferation, repertoire degeneracy, increase of the memory cell type, decreased numbers of naive cells, and shift from $\mathrm{T}$ helper $_{1}$ (Th1) to $\mathrm{T}$ helper 2 (Th2) response. It is noteworthy that the $\mathrm{T}$ helper ${ }_{1}$ phenotype is characterized by a pro-inflammatory status and a resistance to infectious agents, whereas the $\mathrm{T}$ helper ${ }_{2}$ phenotype is characterized by an anti-inflammatory status.

Previously, we reported that a combination of immune status index, including high $\mathrm{T}$ cell proliferation, high $\mathrm{CD} 4{ }^{+}$ cells in relation to $\mathrm{CD} 8^{+}$cells, can predict survival over a 2year follow-up in very old people [46]. In our previous review, we have evaluated the changes in physical activityinduced innate immunity [47]. The aim of the present review is to evaluate the changes that physical activity has on adaptive immunity and examining the alterations of acquired immunity both with aging and physical activity. 
Table 1 T lymphocytes in elderly

\begin{tabular}{ll}
\hline Parameter & Description \\
\hline Naïve T cells (CD45RA) & Decreased \\
Memory T cells (CD45RO+) & Increased \\
CD28 expression & Decreased \\
Mean length of telomeres & Decreased \\
CD4 apoptosis & Increased \\
CD8 apoptosis & Decreased
\end{tabular}

$C D$ Cluster of differentiation

\section{Immunity in the elderly}

\section{Thymus}

The thymus is a central lymphoid organ that lies within the superficial region of the superior mediastinum. It is responsible for $\mathrm{T}$ lymphocytes development $[22,76]$. The involution aging dependent of thymus is characterized by a progressive reduction in size and weight, about 3\% per year until middle age and $1 \%$ per year for the rest of its life [21]. The loss of thymocytes and epithelial cells is replaced by adipose tissue. The decreased proliferation and differentiation of thymocyte is dependent on the reduced production by thymic epithelial cells (TECs) of thymic-hormonal factors, such as thymulin, thymopentin, and thymosines [52].

The molecular mechanism underlying thymus involution has not been fully resolved. It has been hypothesized as a correlation between aging of TECs with reduced expression of MHC molecules and decreased production of thymopoietic cytokines $[2,16]$. As a consequence, the output of new $\mathrm{T}$ cells to the peripheral $\mathrm{T}$ cell pool declines with age. However, the phenotypes of all expected thymic T-cells intermediates are present; there is evidence of cell proliferation as determined by $\mathrm{Ki} 67$ antigen expression and of rearrangement of T-cell receptor gene [72, 73]. Therefore, the age-related loss in thymic tissue is quantitative rather than qualitative.

Post-thymic differentiation involves changes in the expression of CD45 isoforms, cell surface glycoproteins with tyrosine phosphatase function, as well as other markers that discriminate between naïve and memory $\mathrm{T}$ cells. Moreover, several studies addressed to the effect of thymectomy on peripheral T-cell numbers in humans, demonstrated that thymectomy in adults had no effect upon absolute numbers of $\mathrm{CD}^{+}$and $\mathrm{CD}^{+} \mathrm{T}$ cells or upon the ratio of naïve and memory $\mathrm{T}$ cells $[31,78]$. Additionally, defective Fas signaling play a crucial role in the progression of thymic atrophy with aging. Thymic involution was experimentally prevented following the insertion of a Fas transgene abolishing the resistance to apoptosis of $\mathrm{T}$ cells in aged mice and prevents thymic involution [85]. Furthermore, thymic involution can be affected by other microenvironmental factors including hormones and cytokines. Interestingly, melatonin, the main neurohormone of the pineal gland can correct many of the age-related declines of thymic endocrine activity as well as immune dysfunction observed in thymocytes, peripheral blood lymphocytes, and spleen cells [51]. Recent studies demonstrated that IL-12 play a crucial role in the inhibition of thymic involution affecting the thymocyte-negative selection process [43]. It has been observed that IL-12, in combination with IL-2 and IL-7, allows to an increased proliferative response, induced by the latter cytokines on thymocytes [41].

\section{T lymphocytes}

The major changes in immunosenescence occur in T-cell populations, leading to reduced cellular-mediated responses [65].

The decrease of the immunological functions in the elderly could be caused by a decline in the number of $\mathrm{T}$ cells or by a deterioration of T-cell functions (Table 2). Analytical investigations reveal age-related changes in the peripheral $\mathrm{T}$ cell pool, in the predominant phenotype, cytokine production profiles, signaling function, and in replicative ability following stimulus with antigen, mitogens or anti-CD3 antibody [64]. Counts of T-cell subpopulations give controversial results; however, it is more possible to find an increased number of $\mathrm{CD}^{+}$.

As mentioned before, the changes in the behavior of peripheral $\mathrm{T}$ cells are thought to be causally linked to an age-associated thymic involution. Early thoughts on ageassociated immune dysfunction are centered on the number of T lymphocytes. Although from this decreased output one would expect a reduced number of cells in the T-cell pool, a comparison to the total numbers of T cells in old and young individuals failed to show any significant difference [34].

Table 2 Function of T cells in elderly

Function

Reduced response to receptor stimulations and an altered proliferative capacity

Decreased IL-2 and decreased expression of IL-2 receptor

Increased production of inflammatory cytokines: TNF $\alpha$, IFN $\gamma$, IL-6, TGF- $\beta$

Altered response to influenza vaccine

Reduced proliferative response to mitogens

Decreased capacity to maintain a repertoire of TCR

Decreased cytolitic activity

TCR T-cell receptor, TNF $\alpha$ tumor necrosis factor alpha, IFN $\gamma$ interferon gamma, $I L-6$ interleukin $6, T G F-\beta$ transforming growth factor beta 
In humans, aging leads to a decline in T-cell proliferation and in the production of and response to IL-2 $[23,56]$. Several evidence show that shifts in T-cell subsets, particularly shifts from the naïve to the subset of previously activated memory $\mathrm{T}$ cells, may contribute to age-related changes in T-cell function [6].

The reduced cell-mediated response characterizing elderly subjects seems to be dependent on altered phenotypes of $T$ cells. It has been observed that there is a conspicuous decrease in naïve $\mathrm{T}$ cells (CD45RA); meanwhile, the proportion of memory $\mathrm{T}$ cells $\left(\mathrm{CD} 45 \mathrm{RO}^{+}\right)$increases [48]. The functional alterations of the $\mathrm{T}$ cells depend on the increase of the $\mathrm{CD}^{2} 5 \mathrm{RO}^{+}$, which are generally thought to have a poor capacity of activation [69], although others suggested that these cells may have an improved capacity of activation [44], as well as a different production of cytokines [74].

The decline of T-cell responses might be related to an increased activity of indoleamine 2-3 dyoxigenase, an enzyme located on APC, which is responsible for decreased levels of tryptophan surrounding $\mathrm{T}$ lymphocytes. Higher activity, found in nonagenarians, is likely due to infectious and inflammatory stimuli, and it could be considered as a predictor of mortality [67].

Regarding the $\mathrm{CD}^{+} \mathrm{T}$ cells, some authors sustain that serum IL-7 levels, especially decreased levels, and IL-7R expression played a remarkable role on high frequency of $\mathrm{CM}$ (central memory) $\mathrm{CD}^{+}$cells and a decreased frequency of EM (effector memory) $\mathrm{CD} 4^{+}$cells. This change may affect, in aging, the development of long memory $\mathrm{CD}^{+} \mathrm{T}$ cell immune responses to pathogens in vivo, as an altered $\mathrm{T}$ cell immune response to influenza vaccine [37].

The increased proportion of memory $\mathrm{T}$ cells might be due either to loss in the regulation of the cell cycle and DNA repair or to a missing apoptotic activity caused by the p53 deficiency [63] as well as the decreased expression of the Fas antigen (CD95) [1].

Recently, it has been observed that the increased apoptosis in the naïve $\mathrm{CD} 8^{+}$cells was associated with increased cleavage of both caspase- 8 and caspase- 3 compared to young subjects [30].

The total activation of $\mathrm{T}$ cells occurs along primarily two distinct but synergistic signals [36]. The first signal delivered through the T-cell antigen receptor is provided by antigen itself and is responsible for the specificity of the immune response. The second signal, or co-stimulatory signal, is not antigen-related. Many T-cell molecules may serve as receptors for co-stimulatory signals; the CD28 molecule is the best characterized of these molecules [42, 53]. In the elderly, a wide pool of $\mathrm{CD} 28^{-} \mathrm{CD} 8^{+} \mathrm{T}$ cells is present. In some of these people, the pool could increase, reaching more than $50 \%$ of $\mathrm{CD} 8^{+}$total pool. This presence may allow the appearance of latent infections, such as VZV (shingles) and EBV (lymphomas), as well as a reduced control over acute infection with a repeatedly encountered virus (influenza), well documented in elderly persons [14].

A topic that deserves emphasis is the critical role of costimulation in T-cell responses. In the absence of costimulatory signals, a $\mathrm{T}$ cell encountering an antigen undergoes abortive activation, short of proliferation and production of appreciable amounts of cytokines and becomes unresponsive to appropriate stimulation for up to several weeks [24] or undergoes programmed cell death [54].

\section{B lymphocytes}

In contrast to numerous studies of age-associated alterations of T-cell function, those involving B-lymphocyte function or humoral immunity are relatively few. However, aging influences both the quantity and the quality of humoral immunity (Table 3).

Quantitative changes include an altered number of immunoglobulin and antigen-specific Ig-secreting B cell.

Qualitative changes include shift in the number and activity of B-cell subsets as well as shift in the antibody repertoire with respect to the specificity, isotype, and idiotype [19]. However, some authors found neither evidence for a global loss of B-cell function nor the total number of B cells or of Ig-secreting B cells which were decreased [84].

A similarity, as observed with T-cell antigen receptor (TCR), has been found for the repertoire of antibody response by B cells, associated with age-related changes in the germline immunoglobulin repertoire and a marked decline of somatic mutation in germinal centers of aged mice $[50,77,83]$. Somatic mutation designates the process of gene rearrangement that takes place in somatic maturing B cells but not in germline cells, followed by selective survival of those B cells, whose binding immunoglobulinmutated surfaces have developed high affinity toward the corresponding antigen. Additionally, aged mice fail to express B7-2, a co-stimulatory molecule normally expressed by B cells in the germinal centers of young mice in response to T-cell-dependent antigens [49].

Table 3 B lymphocytes in elderly

\begin{tabular}{ll}
\hline Parameter & Description \\
\hline CD27 and CD40L expression & Decreased \\
Antibody affinity & Decreased \\
Serum Ab specific for foreign Ag & Decreased \\
Serum Ab specific for self Ag & \\
\hline Ag: Antigen & \\
Ab: Antibody & \\
CD: Cluster of differentiation &
\end{tabular}


In aging mice, these intrinsic defects of B cells, coupled with the alterations of T-helper cells provide some clues to the abnormalities in the antibody response of aged animals.

Recent evidence shows that the CD 154 (CD40L) expression, essential for the cognate function, was reduced, compared to the younger models [32]. This alteration reflects impaired humoral immune responses, with defects in B-cell proliferation, isotype switching, germinal center formation, and antibody secretion [18].

The first evidence that the humoral immunity changed with age was the report that the quantity of serum antibodies, specific for foreign antigens, declined with age [33]. The antibody response to foreign antigens is also lower in old individuals compared to the youngest, whereas the number of B cells secreting antibodies is enhanced [12]. The B-cell repertoire changes with age and determines an altered ability to recognize antigen [12]. In fact, vaccination seems to stimulate production of antibodies that cross-react with self-antigens in old but not in young mice [7].

The changes in the quality and quantity of antibody contribute to the increased susceptibility and sensitivity of the elderly to infection. It is likely that the B-cell clonal expansions that occur in midlife are the precursors of late life.

\section{Immunoglobulins}

B lymphocytes have been investigated in longitudinal studies, and they are numerically reduced [25]. It has been suggested that aging is associated with the appearance of Bcell clonal expansion, which not only limits the diversity of the B-cell repertoire but likely induces monoclonal serum immunoglobulins and B-cell neoplasm [39, 40]. In humans, the serum concentration of $\operatorname{IgM}, \operatorname{IgA}$, and $\operatorname{IgG}$ also increased with age, although the concentration of $\operatorname{IgD}$ decreased [13]. In contrast to the increase in the steady level of serum $\operatorname{IgG}$ and $\operatorname{IgM}$ with age, the number of antigen-specific IgG and IgM-producing cells stimulated by immunization is decreased in old mice compared to young [28]. These studies showed that there was a greater loss of IgG-producing compared to IgM-producing cells. The preferential loss of $\mathrm{IgG}$ antigen-specific antibody reflects an age-associated defect in isotype switching as a consequence of impaired T-cell function required for the generation of germinal centers and for isotype switching [79]. The ability of B cells to generate antibody responses changes with age, although much of this is related to declining T-cell function [20]. Some murine studies have shown that the antibodies produced by old mice has a lower affinity for its target and it is less effective in preventing infections [33, 57]. In another experience, performed on nonagenarians, serum levels of $\operatorname{IgM}, \operatorname{IgG}$, and $\operatorname{IgA}$ have been measured. The last two were highest and related to greater mortality. Particularly, IgA, reactive protein $\mathrm{C}$ (RPC), and IL-6 are index of intestinal inflammation and/ or a defect in mucosal defence [35].

\section{Physical activity and acquired immunity}

Physical activity leads to several changes in leucocyte subpopulations, involving both innate immunity [47] and acquired immunity.

It is of remarkable note to know the type, duration, and intensity in any kind of exercise, because these peculiarities have much influence on immunity alterations.

After intensive running for 2.5-3 h, leucocytosis has been shown in venous blood of young adults, with a peak $3 \mathrm{~h}$ post-run, then leucocytes returned to baseline level by the next morning. The increased values were mostly due to granulocytes and, in a lesser percentage, to monocytes [59].

Lymphocytes, instead, came out from the vascular compartment. T lymphocytes and natural killer (NK) cells were mainly responsible for lymphocitopenia, instead of B lymphocytes which do not have any role [59].

During and immediately after a marathon, it has been observed that there is an increase in the absolute number of $\mathrm{T}$ lymphocytes, but they were lower $30 \mathrm{~min}$ after the end of a treadmill exercise [10].

The recruitment of all lymphocytic subsets $\left(\mathrm{CD}^{+} \mathrm{T}\right.$, $\left.\mathrm{CD}^{+} \mathrm{T}, \mathrm{CD} 16^{+} \mathrm{NK}, \mathrm{CD} 56^{+} \mathrm{NK}, \mathrm{CD} 19^{+} \mathrm{B}\right)$ raised the lymphocyte blood levels [66]. In the recovery period after intensive exercise, immune changes as decreased lymphocytes count, neutrophilia, and suppressed T and NK cells function are likely due to the release of glucocorticoids during exhausting and long duration of physical activity. In fact, if an exercise lasts lesser than $90 \mathrm{~min}$, the adrenaline recruits lymphocytes into the blood compartment, instead of 2.5-3 h of intensive running, which leads to unchanged lymphocytes levels because of a prevalent concentration of cortisol during the recovery period [62].

Another aspect to point out is the function of $\mathrm{T}$ and $\mathrm{B}$ cells. The human lymphocytes are tested in vitro with some mitogens able to induce proliferative response, as the antigens do in vivo.

Lymphocytes exhibited different sensibility to the most used mitogens, thus, $\mathrm{T}$ cells were stimulated primarily by PHA (phytoaemagglutinin), Con-A (concanavalin-A) and, in a lesser degree, by poke weed mitogen (PWM). B cells were more responsive to stimulation by PWM [58].

Increased values during intensive training were found by Bay et al. [4] in athlete lymphocytes, which were stimulated with PHA and anti-CD3 monoclonal antibody, but elite cyclists during low training periods have shown some differences with values found in non-athletes. These data were not confirmed by Nieman et al. [61], which did not 
demonstrate differences between runners and non-athletes, after mitogen stimulation.

Tvede et al. [75] found that athletes did not show mitogen-induced lymphocyte proliferation during high or low training as non-athlete subjects.

After stimulation with Con-A, marathoners had a fall of $30-40 \%$ for $3 \mathrm{~h}$ after $2.5 \mathrm{~h}$ of intensive running; furthermore, in endurance race events, it was measured and found to have a greater decrease [62].

The exercise is responsible in alterations of total lymphocyte count and in distribution of lymphocyte subpopulations, which has a great influence in lymphocyte proliferative capacity [58].

The diminished responsiveness to PHA and Con-A was largely imputable to $\mathrm{CD} 4+$ and $\mathrm{CD} 8+$ fractions that fell with exercise [58]. However, CD16 + NK fraction increased during exercise, leading to increased lymphocyte proliferation after stimulation with IL-2 [58].

\section{Physical activity in elderly people}

Also in the elderly, exercise programs could interfere with the modifications aging induced to the immune system (Table 4).

In male and female elderly athletes, undergone to endurance activity training, it has been reported that there was an increase in lymphocyte proliferation following mitogen stimulation [60, 70].

Active elderly people, practising regularly long term and moderate physical activity, showed a higher responsiveness than sedentary control group, when lymphocytes were stimulated with anti-CD3 monoclonal antibody [29], which, as well as PHA and PWM, shows a significant influence on lymphocytes of active elderly people [70].

In contrast, the study carried out in elderly women by Flynn et al. [17] reported no significant changes on lymphocyte proliferation after mitogen stimulation or immediately at the end of the exercise of resistance training neither during recovery period. Furthermore, in the experience of Cedda et al., the proliferative responses at most doses of Con-A and PHA was lower than the young control group, and even the elderly had high percentages of CD3+

Table 4 Variations of acquired immunity in the elderly through the physical activity

\begin{tabular}{|c|c|c|}
\hline Parameter & $\begin{array}{l}\text { Effect of } \\
\text { aging }\end{array}$ & $\begin{array}{l}\text { Effect of physical } \\
\text { activity }\end{array}$ \\
\hline Naive T cells & Decreased & Increased \\
\hline Memory $\mathrm{T}$ cells & Increased & Decreased \\
\hline Proliferative response to mitogens & Decreased & Increased \\
\hline Response to influenza vaccine & Altered & Improved \\
\hline
\end{tabular}

cells [11]. The total number of leucocytes in exercising elderly people increases as that which occurs in the in the young adults [3]. The levels were measured both immediately after the exercise and $4 \mathrm{~h}$ post-run, exhibiting highly significant increase [3], even though elderly subjects who underwent the maximal exercise treadmill test, showed preexercise values after $20 \mathrm{~min}$ by the end of exercise [11]. The lymphocytic population raised lesser than leucocytes, immediately after the exercise [3]. The subsets of $\mathrm{T}$ lymphocytes were greatly influenced by physical activity. It was remarkable that there was an increase in the CD4 $4^{+}$ cells, while $\mathrm{CD}^{+}$cells were unchanged [3], thus CD4/CD8 ratio was also found to be increased [3, 9, 70]. In the sedentary control group, it has been found that there were alterations in adaptive immunity as an imbalance between $\mathrm{T}$ and $\mathrm{B}$ lymphocytes due to decreased $\mathrm{T} \mathrm{CD}^{+}$, increased CD20 B cells [82]. Furthermore, the release of cytokines owning to Th2 pattern stimulated B cell clone proliferation, which was responsible of enhanced antibody production and the following occurring in autoimmune disorders [82].

These alterations were not present in active elderly people, who enjoy practicing swimming, cycling, or jogging, thereby T-cell/B-cell ratio had unvaried results. [82].

Extremely important is the effect of exercise relative to naïve and memory cell subsets, which is mainly responsible for the response to infectious diseases. Woods et al. reported an increased percentage and number of CD40and CD8-naïve cells (CD45RA+) and a decrease in CD4+ memory cells $(\mathrm{CD} 45 \mathrm{RO}+)$ after 6 months of moderate exercise training [80], though these results were found in the elderly control group, as well. Furthermore, they demonstrated that CD4 and CD8 memory cells were reduced in the spleen of mice that underwent exercise, implying a raise in naïve/memory cell ratio. Likely, the exercise resulted in apoptosis of memory T cells [81].

An experience carried out on thymus mice has shown that exercise in old mice did not modify the aging-related changes, as thymic weight, percentages of $\mathrm{CD}^{-} / \mathrm{CD}^{-}$, $\mathrm{CD}^{+} / \mathrm{CD}^{+}$, and single positive cells [81].

The major susceptibility to infections, found in elderly people, is clearly due to a reduced capacity of the immune system to generate a strong response to novel antigenic stimuli, as well as the impairment of immunoglobulin (Ig) response, making the vaccination unsuccessful [26, 68]. Although the data on the changes in serum Ig after physical activity are scanty, Smith et al. [71] have given, through their experience in old men, useful information. They demonstrated that in physically active old men, the response to novel protein antigen keyhole-limpet hemocyanin (KLH) was enhanced. They measured the anti-KLH $\mathrm{IgM}, \mathrm{IgG}$, and IgG1 serum levels in old people and in old active men, finding increased values in the last group, 
independent of the total concentration of antibodies. Furthermore, Kohut et al. [38] sustained that trained elderly people had a better anti-influenza response to influenza vaccination. Unlike, Bruunsgaard et al. [8], data reported no changes in tri-athletes, after a race, in response to diphtheria, tetanus, and pneumococcal vaccination, suggesting that humoral immunity was not affected by intensive exercise.

The antibody isotype showed any changes after exercise, in fact, elderly people, following long-term regular exercise displayed increased levels of IgA and IgM [9]. Unlike what has been observed in elite swimmers, who trained for 7 months, IgA, IgM, and IgG levels were $10 \%$ lower than the clinical norms [27].

\section{Conclusions}

The regressing pathway of the thymus in every human being influences negatively the essential function of adaptive immunity.

The fragility of the elderly is more evident when they encounter a novel antigenic challenge, showing a great difficulty to face it up, likely enhancing, in certain cases, the risk of mortality (e.g., influenza pneumonia).

In elderly subjects practicing regularly moderate exercise training, some aspects of immunosenescence are attenuated or improved, both innate immunity [47] and acquired immunity, as the reduction of memory cells and the increase of naïve $\mathrm{T}$ cells $[79,80]$ increase further the production of primary antibody response [71].

It is much clear that regular exercise could help in maintaining the well-being in elderly people. However, this point of view is not entirely inquired nowadays; thus, it deserves further experiences. In fact, with the increasing number of older people every way, giving an enhancement of immune function could improve the quality of life during aging. Thereby, the physical activity may represent the "gold standard", given that it is not very expensive, and it allows socializing, improving mental and physical conditions at last.

\section{References}

1. Aggarwal S, Gupta S (1998) Increased apoptosis of T cell subsets in aging humans: altered expression of Fas (CD95), Fas ligand, Bcl-2 and Bax. J Immunol 160:1627-1637

2. Andrew D, Aspinall R (2002) Age-associated thymic atrophy is linked to a decline in IL-7 production. Exp Gerontol 37:455

3. Bauer T, Weisser B (2002) Effect of aerobic endurance exercise on immune function in elderly athletes. Schweiz Rundsch Med Prax 91(5):153-158

4. Bay Z, Kantorski J, Majewska E, Zeman K, Pokoca L, Fornalczyk E, Tchòrzewski H, Sulowka Z, Lewicki R (1994) Immunological status of competitive cyclists before and after the training season. Int J Sports Med 15:319-324

5. Bender BS, Nagel JE, Adler WH (1986) Absolute peripheral blood lymphocyte counts and subsequent mortality of elderly man. The Baltimore Longitudinal Study of Aging. J Am Geriatr Soc 34:649-654

6. Beverley P (1991) Immunological memory in T cell. Curr Opin Immunol 3:355-360

7. Borghesi C, Nicoletti C (1994) Increase of cross (auto)-reactive antibodies after immunization in aged mice: a cellular and molecular study. Int J Exp Pathol 75:123-130

8. Bruunsgaard H, Hartkopp A, Mohr T, Konradsen H, Heron I, Mordhorst CH, Pedersen BK (1997) In vivo cell-mediated immunity and vaccination response following prolonged, intense exercise. Med Sci Sports Exerc 29:1176-1181

9. Buyukyazi G (2004) Differences in the cellular and humoral immune system between sedentary and endurance-trained elderly males. Sci Sports 19:130-135

10. Castell LM, Poortmans JR, Leclercq R, Brasseur M, Duchateau J, Newsholme EA (1997) Some aspects of the acute phase response after a marathon race, and the effects of glutamine supplementation. Eur J Appl Physiol 75:47-53

11. Ceddia MA, Price EA, Kohlmeier CK, Evans JK, Lu Q, McAuley E, Woods JA (1999) Differential leukocytosis and lymphocyte mitogenic response to acute maximal exercise in the young and old. Med Sci Sports Exerc 31(6):829-836

12. Colonna-Romano G, Bulati M, Aquino A, Scialabba G, Candore G, Lio D, Motta M, Malaguarnera M, Caruso C (2003) B-cell in the aged: CD27, CD5 and CD40 expression. Mech Ageing Dev 124:389-393

13. De Greef GE, Van Staalduinen GJ, Van Doorninck H (1992) Agerelated changes of the antigen-specific antibody formation in vitro and PHA-induced T-cell proliferation in individuals who met the health criteria of the SENIEUR protocol. Mech Ageing Dev 566:1-14

14. Effros RB (2001) Immune system activity. Handbook of the biology of ageing, 5th edn. Academic Press, San Diego

15. Facchini A, Mariani E, Mariani AR (1987) Increased number of circulating Leu 11+(CD16) large granular lymphocytes and decreased NK activity during human ageing. Clin Exp Immunol 68:340-347

16. Farr AG, Sidman CL (1984) Reduced expression of Ia antigens by thymic epithelial cells of aged mice. J Immunol 133:98

17. Flynn MG, Fahlman M, Braun WA, Lambert CP, Bouillon LE, Brolinson PG, Armstrong CW (1999) Effects of resistance training on selected indexes of immune function in elderly women. J Appl Physiol 86(6):1905-1913

18. Foy TM, Aruffo A, Bajorath J, Buhlmann JE, Noelle RJ (1996) Immune regulation by CD40 and its ligand GP39. Annu Rev Immunol 14:591-617

19. Franceschi C, Valensis S, Fagnoni S, Barbi C, Bonafe M (1999) Biomarkers of immunosenescence within an evolutionary perspective: the challenge of heterogeneity and the role of antigenic load. Exp Gerontol 34:911-921

20. Geiger H, Van Zant G (2002) The aging of lympho-hematopoietic stem cells. Nat Immunol 3:329-333

21. George AJ, Ritter MA (1996) Thymic involution with ageing: obsolescence or good housekeeping? Immunol Today 17:267-272

22. Gill J, Malin M, Sutherland J, Gray D, Hollander G, Boyd R (2003) Thymic generation and regeneration. Immunol Rev 195:28

23. Gillis S, Kozak R, Durante M, Weksler ME (1981) Immunological studies of aging. Decreased production of and response to $\mathrm{T}$ cell growth factor by lymphocytes from aged humans. J Clin Invest 67:937-942

24. Gimmy CD, Freeman GJ, Gribben JG, Gray G, Nadler LM (1993) Human T-cell clonal anergy is induced by antigen presentation $n$ the absence of B7 costimulation. Proc Natl Acad Sci USA 90:6586-590 
25. Ginaldi L, De Martinis M, D’Ostilio A, Marini L, Loreto MF, Corsi MP, Quaglino D (1999) The immune system in the elderly: specific humoral immunity. Immunol Res 20:101-108

26. Glathe H, Lange W (1995) Influenza vaccination in older patients. Immunogenicity, epidemiology and available agents. Drugs Aging 6:368-387

27. Gleeson M, McDonald WA, Cripps AW, Pyne DB, Clancy RL, Fricker PA (1995) The effect on immunity of long-term intensive training in elite swimmers. Clin Exp Immunol 102:210-216

28. Goidl EA, Innes JB, Weksler ME (1976) Immunological studies of aging. II. Loss of Ig and high avidity plaque-forming cells and increased suppressor cell activity in aging mice. J Exp Med 144:1037-1048

29. Gueldner SH, Poon LW, La Via M, Virella G, Michel Y, Bramlett MH, Noble CA, Paulling E (1997) Long term patterns and immune function in healthy older women. A report of preliminary findings. Mech Ageing Dev 93:215-222

30. Gupta S, Gollapudi S (2006) TNF- $\alpha$ induced apoptosis in human naïve and memory $\mathrm{CD} 8^{+} \mathrm{T}$ cells in aged humans. Exp Gerontol 41 (1):69-77

31. Haynes B, Hargen E, Olanow C, Eisenbarth G, Wechsler A, Hensley L, Roses A (1983) Effect of thymectomy on peripheral lymphocyte subsets in myasthenia gravis: selective effect on Tcells in patients with thymic atrophy. J Immunol 131:773-777

32. Haynes L, Eaton SM (2005) The effect of age on the cognate function of $\mathrm{CD}^{+} \mathrm{T}$ cells. Immunol Rev 205:220-228

33. Hu A, Ehleiter D, Ben-Yeuda A (1993) Effect of age on the expressed B cell repertoire: role of B cell subsets. Int Immunol 5:1035-1039

34. Hulstaert F, Hannet I, Deneys V, Munhyeshuli V, Reichert T, De Bruyere M, Strauss K (1994) Age-related changes in human blood lymphocyte subpopulations. II. Varying kinetics of percentage and absolute count measurements. Clin Immunol Immunopathol $70: 152-158$

35. Hurme M, Paavilainen PM, Pertovaara M, Jylha M, Karhunen PJ, Hervonen A, Lehtimaki T (2005) Ig A levels are predictors of mortality in Finnish nonagenarians. Mech Ageing Dev 126(67):829-831

36. Janeway CA Jr, Bottanly K (1994) Signals and signs for lymphocytes responses. Cell 76:275-85

37. Kang I, Myung SH, Nolasco H, Park SH, Dan JM, Choi J, Craft J (2004) Age associated change in the frequency of memory CD 4 $\mathrm{T}$ cells impairs long term $\mathrm{CD} 4 \mathrm{~T}$ cell responses to influenza vaccine. J Immunol 173:673-681

38. Kohut ML, Cooper MM, Nickolaus MS, Russell DR, Cunnick JE (2002) Exercise and psychosocial factors modulate immunity to influenza vaccine in elderly individuals. J Gerontol A Biol Sci Med Sci 57:M557-M562

39. Lacroix-Desmazes S, Mouthon L, Kaveri SV, Kazatchkine MD, Weksler ME (1999) Stability of natural self-reactive antibody repertoire during aging. J Clin Immunol 19:26-34

40. Leone G, Mele L, Pulsoni A, Equitani F, Pagano L (1999) The incidence of secondary leukemias. Haematologica 84:937-945

41. Li L, Hsu HC, Stockard CR, Yang P, Zhou J, Wu Q, Grizzle WE, Mountz JD (2004) IL-12 inhibits thymic involution by enhancing IL-7 and IL-2-induced thymocyte proliferation. J Immunol 172:2909-2916

42. Linsley PS, Ledbetter JA (1993) The role of the CD28 receptor during T cell responses to antigen. Ann Rev Immunol 11:191-212

43. Ludviksson BR, Ehrhardt RO, Strober W (1999) Role of IL-12 in intrathymic negative selection. J Immunol 163:4349

44. Mackay CR (1993) Immunological memory. Add Immunol 53:217-265

45. Malaguarnera L, Ferlito L, Imbesi RM, Gulizia GS, Di Mauro S, Maugeri D, Malaguarnera M, Messina A (2001) Immunosenescence: a review. Arch Gerontol Geriatr 31:1-14
46. Malaguarnera L, Ferlito L, Di Mauro S, Imbesi RM, Scalia G, Malaguarnera M (2001) Immunosenescence and cancer: a review. Arch Gerontol Geriatr 32:77-93

47. Malaguarnera L, Cristaldi E, Vinci M, Malaguarnera M (2008) The role of exercise on the innate immunity of the elderly. Eur Rev Aging Phys Act 5:43-49

48. Malaguarnera M, Laurino A, Di Mauro S, Motta M, Di Fazio I, Maugeri D (2000) The comorbidities of elderly oncologic patients. Arch Gerontol Geriatr 30:237-244

49. Miller C, Kelsoe G, Hua S (1994) Lack of B7-2 expression in the germinal centers of aged mice. Age Immunol Infect Desease 5:249-252

50. Miller C, Kelsoe G (1995) IgVH hypermutation is absent in the germinal centers of aged mice. J immunol 155:3377-3384

51. Mocchegiani E, Santarelli L, Fabris N (1994) Thymic endocrine function in neuroendocrine human diseases. Ann N Y Acad Sci $741: 115-123$

52. Mocchegiani E, Giacconi R, Cipriano C, Muti E, Gasparini N, Malavolta M (2004) Are zinc-bound metallothionein isoforms (I+II and III) involved in impaired thymulin production and thymic involution during ageing? Immun Ageing 1:5

53. Motta M, Ferlito L, Malaguarnera L, Vinci E, Bosco S, Maugeri D, Malaguarnera M (2003) Alterations of lymphocytic set-up in elderly patients with cancer. Arch Gerontol Geriatr 36:7-14

54. Moulias R, Raynaud-Simon A, Moulinas S, Meaume S (2002) Immunity, autoimmunity and the aging process: complex interaction. Ann Med Interne 153:441-445

55. Murasko DM, Weiner P, Kaye D (1988) Association of lack of mitogen-induced lymphocyte proliferation with increased mortality in the elderly. Aging Immunol Infect Dis 1:1-6

56. Nagel JE, Chopra RK, Chrest FJ, McCoy MT, Schneider EL, Holbrook NJ, Adler WH (1988) Decreased proliferation, interleukin-2 synthesis, and interleukin-2 receptor expression are accompanied by mRNA expression in phytohemagglutinin-stimulated cells from elderly donors. J Clin Invest 81:1096-1102

57. Nicoletti C (1995) Antibody protection in aging: influence of idiotypic repertoire and antibody binding activity to a bacterial antigen. Exp Mol Pathol 62:99-108

58. Nielsen HB, Pedersen BK (1997) Lymphocyte proliferation in response to exercise. Eur J Appl Physiol 75:375-379

59. Nieman DC, Berk LS, Simpson-Westerberg M, Arabatzis K, Youngberg W, Tan SA, Eby WC (1989) Effects of long endurance running on immune system parameters and lymphocyte function in experienced marathoners. Int J Sports Med 10:317-323

60. Nieman DC, Henson DA, Gusewitch G, Warren BJ, Dotson RC, Butterworth DE, Nehlsen-Cannarella SL (1993) Physical activity and immune function in elderly women. Med Sci Sports Exerc $25: 823-831$

61. Nieman DC, Buckley KS, Henson DA, Warren BJ, Suttles J, Ahle JC, Simandle S, Fagoaga OR, Nehlsen-Cannarella SL (1995) Immune function in marathon runners versus sedentary controls. Med Sci Sports Exerc 27:986-992

62. Nieman DC, Simandle S, Henson DA, Warren BJ, Suttles J, Davis JM, Buckley KS, Ahle JC, Butterworth DE, Fagoaga OR, Nehlsen-Cannarella SL (1995) Lymphocyte proliferative response to 2.5 hours of running. Int J Sports Med 16:404-408

63. Ohkusu-Tsukada T, Isobe K (1999) Accelerated development and aging of the immune system in p53-deficient mice. J Immunol 163:1966-1972

64. Pawelec G (2003) Immunosenescence in Montecatini. Biogerontology 4:121-123

65. Pawelec G, Akbar A, Caruso C, Solana R, Grubeck-Loebenstein B, Wikby A (2005) Human immunosenescence: is it infectious? Immunol Rev 205:257-268

66. Pedersen BK, Toft AD (2000) Effects of exercise on lymphocytes and cytokines. Br J Sports Med 34:246-251 
67. Pertovaara M, Raitala A, Lehtimäki T, Karhunen PJ, Oja SS, Jylha M, Hervonen A, Hurme M (2006) Indoleamine 2,3-dioxygenase activity in nonagenarians is markedly increased and predicts mortality. Mech Ageing Dev 127:497-499

68. Powers DC (1994) Effect of age on serum immunoglobulin G subclass antibody responses to inactivated influenza virus vaccine. J Med Virol 43:57-61

69. Shi J, Miller RA (1993) Differential tyrosine-specific protein phosphorylation in mouse $\mathrm{T}$ lymphocyte subsets. J Immunol 151:730-739

70. Shinkai S, Kohno H, Kimura K, Komura T, Asai H, Inai R, Oka K, Kurokawa Y, Shephard R (1995) Physical activity and immune senescence in men. Med Sci Sports Exerc 27(11):1516-26

71. Smith TP, Kennedy SL, Fleshner M (2004) Influence of age and physical activity on the primary in vivo antibody and T cellmediated responses in men. J Appl Physiol 97:491-498

72. Steinmann G, Klaus B, Muller-Hermelink H (1985) The involution of aging human thymic epithelium is independent of puberty. Scand J Immunol 22:563-575

73. Steinmann G (1986) Changes in the human thymus during aging. Curr Top Pathol 75:43-80

74. Swain SL, Croft PA, Dubey C, Haynes L, Rogers P, Zhang X, Bradley LM (1996) From naive to memory T cells. Immunol Rev 150:143-167

75. Tvede N, Steensberg J, Baslund B, Kristensen JH, Pedrsen BK (1991) Cellular immunity in highly-trained elite racing cyclists and controls during periods of training with high and low intensity. Scand J Sports Med 1:163-166

76. van Ewijk W (1991) T-cell differentiation is influenced by thymic microenvironments. Annu Rev Immunol 9:591
77. Viale AC, Chies JA, Huetz F, Malenchere E, Weksler M, Freitas AA, Coutinho A (1994) VH-gene family dominance in ageing mice. Scand J Immunol 39:184-188

78. Watanabe K, Sato K, Biernat W, Tachibana O, von Ammon K, Ogata N, Yonekawa Y, Kleihues P, Ohgaki H (1997) Incidence and timing of p53 mutations during astrocytoma progression in patients with multiple biopsies. Clin Cancer Res 3(4):523530

79. Weksler ME (2000) Changes in the B-cell repertoire with age. Vaccine 18:1624-1628

80. Woods JA, Ceddia MA, Wolters BW, Evans JK, Lu Q, McAuley E (1999) Effects of 6 months of moderate aerobic exercise training on immune function in the elderly. Mech Ageing Dev 109:1-19

81. Woods JA, Ceddia MA, Zack MD, Lowder TW, Lu Q (2003) Exercise training increases the naïve to memory $\mathrm{T}$ cell ratio in old mice. Brain Behav Immun 17:384-392

82. Yan H, Kuroiwa A, Tanaka H, Shindo M, Kiyonaga A, Nagayama A (2001) Effect of moderate exercise on immune senescence in men. Eur J Appl Physiol 86:105-111

83. Yang X, Stedra J, Cerny J (1994) Repertoire diversity of antibody response to bacterial antigens in aged mice. IV: study of $\mathrm{VH}$ and VL gene utilization in specific antibody foci by in situ hybridization. J Immunol 152:2214-2221

84. Zhao KS, Wang YF, Gueret R, Weksler ME (1995) Dysregulation of the humoral immune response in old mice. Int Immunol 7:929 934

85. Zhou T, Edwards CK, Mountz JD (1995) Prevention of agerelated $\mathrm{T}$ cell apoptosis defect in CD2-Fas-transgenic mice. J Exp Med 182:129-137 